\title{
Kewajiban Masyarakat menerima Edukasi Kesehatan Mental
}

\author{
Vingki Maulana Putri \\ Institut Ilmu Kesehatan Surya Mitra Husada Indonesia
}

fingkichng95@gmail.com

\begin{abstract}
Abstrak :
Kesehatan mental merupakan komponen mendasar untuk membentuk relasi sosial, menjaga produktivitas, keseimbangan hidup sehari-hari, dan hubungan seimbang dengan lingkungan. Jika individu sehat secara mental, individu akan dapat terus berkembang dan berkontribusi sebagai masyarakat. Beberapa bulan ke belakang, kesadaran masyarakat Indonesia dalam isu kesehatan mental dinilai terus meningkat. Dulu Indonesia mungkin masih menutup mata ketika membahas gangguan jiwa karena dianggap hal yang tabu. Tapi kalau kamu sadar, sekarang sudah banyak beberapa komunitas, kampanye, obrolan di media sosial bahkan karya film yang mengulas tentang kesehatan mental. Meski sudah banyak dibicarakan, kesehatan mental masih dianggap stigma bagi beberapa orang. Dan menganggap bahwa orang dengan masalah kesehatan mental adalah orang gila atau kerasukan setan. Banyak juga yang menganggap orang dengan masalah kejiwaan adalah orang yang kurang pengetahuan agama dan tidak dekat dengan Tuhan. Padahal gangguan kejiwaan adalah kondisi medis di otak.

\section{Latar belakang :}

Kesehatan mental merupakan komponen mendasar untuk membentuk hubungan sosial, menjaga produktivitas, keseimbangan hidup sehari-hari, dan hubungan seimbang dengan lingkungan. Jika individu sehat secara mental, individu akan dapat terus berkembang dan berkontribusi sebagai masyarakat. Sayangnya, isu kesehatan mental di Indonesia masih menjadi stigma yang dapat berdampak buruk pada penderita. Misalnya seperti diskriminasi dan dikucilkan dari masyarakat. Stigma ini dapat menghambat kesembuhan dan pemulihan penderita kesehatan mental dan dapat membuat orang yang menderita gangguan mental memilih bungkam atau tidak berkonsultasi kepada ahli. Akibatnya, berdasarkan data dari Riskesdas pada tahun 2018, 12 juta penduduk berusia di atas 15 tahun mengalami depresi dan 19 juta penduduk di atas 15 tahun mengalami gangguan mental emosional. Maka dari itu, masyarakat kita butuh edukasi pengetahuan akan pentingnya kesehatan mental. Pengetahuan tersebut akan berdampak pada peningkatan pengetahuan umum diantaranya:
\end{abstract}


1. Pengetahuan tentang bagaimana mencegah gangguan mental;

2. Pengetahuan tentang kondisi gangguan mental dasar;

3. Pengetahuan tentang opsi pencarian pertolongan dan perawatan yang tersedia;

4. Pengetahuan tentang strategi pertolongan mandiri yang efektif untuk masalah yang lebih ringan; dan

5. Keterampilan pertolongan pertama untuk mendukung orang lain yang mengalami gangguan mental atau berada dalam krisis kesehatan mental (Kutcher, Wei, \& Coniglio, 2016).

Jika masyarakat terus dilatih kepekaan dan ditingkatkan ilmu pengetahuannya berkaitan dengan hal-hal tersebut, maka isu kesehatan mental akan semakin terbiasa didengar oleh masyarakat dan dapat menjadi bagian pembicaraan sehari-hari. Hal ini akan membantu masyarakat dalam mengakses bantuan yang dibutuhkan sehingga keterampilannya dalam mencari bantuan akan meningkat. Tidak hanya itu, individu akan lebih mudah dan tanggap dalam mengenali tanda-tanda stres yang berdampak buruk pada dirinya dan mempercepat akses pertolongan sesuai gejala yang dialami. Dengan meningkatnya literasi kesehatan mental, stigma dan diskriminasi terhadap orang dengan gangguan/masalah mental akan berkurang sehingga kesejahteraan masyarakat secara psikologis dapat tercapai.

\section{Kasus/Masalah :}

Kejarmimpi-Jakarta - artis korea Choi Jin-ri alias Sulli yang bunuh diri karena depresi? Mantan personil girlband $\mathrm{f}(\mathrm{x})$ ini bukan meninggal gantung diri tapi aksinya dipicu depresi akibat hujatan negatif yang dia terima dari media sosial. Sulli dianggap sebagai perempuan lugu dan periang. Tapi sayangnya, ketika Sulli memposting hal-hal di luar citra baiknya, komentar-komentar negatif datang yang memandangnya buruk atau gagal menjadi idola yang beradab. Ia sendiri sempat mengakui kalau ia mengalami gangguan mental. Tapi sayangnya publik menganggap ia hanya mencari perhatian. Memang kadang orang yang mengalami gangguan mental nggak terlihat di depan bahwa dirinya menderita. Di setiap postingan media sosialnya, Sulli masih terlihat ceria menjalani karirnya sebagai influencer. Dari luar masih bisa tersenyum dan berinteraksi seperti biasa, tapi kalau mereka sendirian bisa tiba-tiba merasakan putus asa sampai ada pikiran dunia ini nggak mendukung dia.

\section{Tinjauan pustaka :}

Gangguan kesehatan mental merupakan suatu kondisi adanya gangguan pada fungsi jiwa yang menimbulkan penderitaan atau hambatan pada seseorang 
dalam melaksanakan peran sosial. Orang dengan kondisi mental yang baik dapat menyadari potensi yang mereka punya, mengatasi tekanan kehidupan, bekerja secara produktif, dan berkontribusi pada komunitas mereka.Gangguan kesehatan mental dibagi menjadi dua golongan, yaitu gangguan mental emosional seperti depresi dan kecemasan serta gangguan jiwa berat. Gangguan mental emosional merupakan keadaan dimana seseorang sedang mengalami gangguan psikologis. Apabila tidak cepat ditanggulangi, gangguan ini akan beresiko lebih serius. Adapun gejala-gejala yang sering dialami oleh orang yang menggalami gangguan mental emosional adalah mempunyai pemikiran untuk mengakhiri hidup, tidak mampu dalam melakukan hal-hal yang bermanfaat dalam hidup, merasa tidak berharga, kehilangan minat pada berbagai hal, dan adanya gangguan dalam melakukan pekerjaan sehari-hari.

Gangguan kesehatan mental dapat dialami oleh semua kelompok usia. Data dari hasil Riskesdas menunjukkan bahwa gangguan kesehatan mental terutama gangguan depresi sudah mulai terjadi sejak usia remaja, yaitu usia 15-24 tahun dengan prevalensi sebesar 6,2\%. Semakin bertambahnya usia, semakin tinggi juga pola prevalensinya. Gangguan depresi merupakan gangguan mental dengan pravelensi tertinggi. Di tahun 2013, prevalensi gangguan mental berupa gejala-gejala depresi sebesar 6\%. Dengan adanya data tersebut, maka semakin jelas bahwa gangguan mental tidak dapat diremehkan begitu saja karena jumlahnya yang sudah mengkhawatirkan dan gejalanya yang bisa terjadi pada siapa saja.

Hingga saat ini, orang yang mengalami gangguan kesehatan mental masih belum mendapatkan pelayanan yang seharusnya didapatkan. Bahkan, orang yang menggalami gangguan jiwa berat masih ada yang dikucilkan, disembunyikan, sampai dipasung karena dianggap sebagai suatu aib keluarga. Sistem kesehatan di dunia juga dianggap belum cukup untuk menanggapi beban gangguan mental yang akhirnya menyebabkan adanya kesenjangan antara kebutuhan akan perawatan dan persediannya yang sangat besar. Di negara berkembang, ada sekitar $85 \%$ orang yang mengalami gangguan kesehatan mental yang tidak dapat ditangani karena kurangnya fasilitas yang tersedia. Selain itu, masih banyaknya stigma keliru yang bersebaran di lingkungan masyarakat tentang gangguan kesehatan mental. Masyarakat beranggapan bahwa gangguan kesehatan mental merupakan hal yang aneh dan tabu untuk dibicarakan. Hal ini mengakibatkan banyaknya penderita gangguan kesehatan mental yang akhirnya memilih untuk menutup diri dari keluarga atau bahkan lingkungan sekitar. Tindakan yang seperti ini dapat menyebabkan hilangnya kesempatan untuk menyelamatkan atau membantu penderita tersebut dan menyebabkan terjadinya kasus bunuh diri akibat gangguan kesehatan mental yang terlambat ditangani. Bahkan, penanganan gangguan kesehatan mental di Indonesia masih dilakukan dengan cara yang tidak sesuai 
prosedur. Masih ada masyarakat yang memilih untuk membawa pasien dengan gangguan kesehatan mental ke dukun atau orang pintar karena beranggapan bahwa gangguan kesehatan mental merupakan akibat dari adanya gangguan makhluk halus.

Menghilangkan stigma negatif terhadap adanya gangguan kesehatan mental dan keterbukaan masyarakat akan masalah tersebut sangat diperlukan karena dengan adanya hal tersebut, masyarakat mampu menyelamatkan lebih banyak orang yang mengalami gangguan kesehatan mental dan mencegah terjadinya tindakan bunuh diri. Selain itu, dengan menghilangkan stigma negatif dan lebih terbuka akan masalah gangguan kesehatan mental juga dapat membantu orang yang mengalami gangguan tersebut agar mendapatkan perlakuan yang sesuai dengan apa yang seharusnya dilakukan. kesehatan mental merupakan hak seluruh manusia, tidak terkecuali ras, suku, agama, gender, dan status sosial. Kesehatan mental berkorelasi kuat dengan kesehatan fisik. Sebuah riset Canadian Mental Health Association (2020) menyatakan bahwa orang dengan kesehatan mental yang rendah akan sering mengalami gangguan kesehatan fisik, begitu pula sebaliknya, orang yang memiliki kesehatan fisik rendah memiliki risiko kesehatan mental yang juga rendah. Maka dari itu, riset juga menyarankan bahwa segala tindakan yang bertujuan untuk mengedukasi masyarakat tentang menjaga kesehatan fisik pun harus menyasar kepada kesehatan mental (Ohrnberger, Fischera, \& Sutton, 2017). Keuntungan dari memberikan edukasi kesehatan mental adalah seseorang yang aware terhadap kesehatan mental akan cenderung memiliki life skill yang diperlukan untuk menghadapi situasi yang sulit, termasuk diantaranya memiliki coping skill yang efektif dan perilaku help seeking behavior yang tinggi (Salerno, 2016). Dalam beberapa riset menjukkan bahwa dukungan sosial diyakini bisa menjadi alat bantu atau penun jang untuk meningkatkan derajat kesehatan sesorang. Hal ini dikarenakan dengan adanya dukungan sosial yang baik maka akan menciptakan sebuah lingkungan yang baik pula. Lingkungan yang baik kana memberikan rasa nyaman yang membuat sesorang merasa dikasih sayangi dan dicintai. Sehingga mampu membentuk suasana emosi yang baik, dan membuat orang tersebut bahagia selalu. Seperti yang sudah banyak dijelaskan dari berbagai sumber bahwa banyak penyakit muncul akibat stress atau keadaan emosional yang kurang baik. Oleh karena itu, perlu dipelajari dan dipahami lagi mengenai dukungan sosial lebih dalam lagi, agar mampu untuk menjadi alat bantu meningkatkan derajat kesehatan seseorang.Selain itu, dengan menghilangkan stigma negatif dan lebih terbuka akan masalah gangguan kesehatan mental juga dapat membantu orang yang mengalami gangguan tersebut agar mendapatkan perlakuan yang sesuai dengan apa yang seharusnya dilakukan.

\section{Pembahasan :}


World Health Organization (WHO, 2001), menyatakan bahwa kesehatan mental merupakan kondisi dari kesejahteraan yang disadari individu, yang di dalamnya terdapat kemampuan-kemampuan untuk mengelola stres kehidupan yang wajar, untuk bekerja secara produktif dan menghasilkan, serta berperan serta di komunitasnya. Sedangkan gangguan kesehatan mental merupakan suatu kondisi adanya gangguan pada fungsi jiwa yang menimbulkan penderitaan atau hambatan pada seseorang dalam melaksanakan peran sosial. Gangguan kesehatan mental dapat dialami semua kelompok usia. Karena jumlahnya yang semakin meningkat dan gejalanya yang bisa terjadi kepada siapa saja, gangguan mental tidak boleh diremehkan begitu saja. Masyarakat perlu diberikan literasi atau edukasi perihal kesehatan mental agar mereka lebih aware dengan sekitar. Tidak lagi memberikan stigma negatif kepada pengidap gangguan mental ataupun kepada gangguan jiwa dan dapat membantu pengidap dengan memberikan perlakuan yang sesuai dengan apa yang seharusnya dilakukan.

Literasi atau edukasi kesehatan mental ini menjadi bersifat wajib. Karena semakin kesini, banyak kalangan anak muda utamanya yang menjadikan gangguan mental sebagai trend di sosial media. Banyak orangtua, atau bahkan orang disekeliling kita yang meremehkan hal ini. Mengucilkan orang-orang yang melakukan pemeriksaan diri ke psikolog atau psikiater. Gangguan mental bukan hal yang lucu sehingga boleh dijadikan ajang tren di sosial media. Dan gangguan mental bukan sebuah aib atau hal yang menjijikan, sehingga masyarakat harus memperlakukan pengidap gangguan mental seperti sampah dan tidak memberikan perlakuan selayaknya kepada manusia. Edukasi kesehatan mental harus benar benar kita wujudkan. Edukasi ini penting untuk diterima oleh masyarakat, terutama oleh para orang tua. Karena sekolah anak pertama kali adalah rumah. Dan orang tua mampu mengajarkan anaknya sejak usia belia mengenal apa itu kesehatan mental. Hal itu akan bermanfaat untuk anak menjadi lebih aware dengan kesehatan mental diri nya sendiri. Edukasi kesehatan mental juga berperan untuk menjadikan masyarakat belajar bagaimana memanusiakan manusia. Ada pun tips-tips untuk kita bagaimana menjaga kesehatan mental. Berikut tips nya :

\section{Kontrol Emosi Kamu}

Belajar untuk tidak mudah tersinggung terhadap apa saja yang dikatakan seseorang, pilah apa yang mereka katakan, dan ambil sisi positifnya.

\section{Mencoba hal baru}

Saat terjadi kekosongan waktu atau kamu mulai merasa bosan dengan aktivitas yang itu-itu saja, maka kamu bisa mengisi waktu dengan mencoba hal-hal baru sendiri atau bersama temanmu. 


\section{Bercerita Kepada Orang Lain}

Bercerita pada orang yang kamu percaya dapat mengurangi beban yang sedang kamu pikul.

\section{Pergi Keluar}

Meskipun hanya 10 menit dalam sehari, luangkanlah waktu untuk duduk atau berjalan di ruang terbuka yang dikelilingi pepohonan dan udara segar. Hal ini secara instan akan mengangkat sedikit banyak tingkat stress dalam pikiran dan mengisi kembali energi dalam tubuh.

\section{Olahraga}

Selalu luangkan waktu untuk berolahraga, makan makanan yang sehat agar berkarya dalam kehidupan ini semakin prima.

\section{Meditasi}

Luangkan waktu untuk diri sendiri dengan cara meditasi. 10-15 menit dalam sehari adalah waktu ideal, terutama sebelum tidur.

7. Senyum

Meskipun terdengar sepele, tapi senyuman selalu dapat mengubah dunia menjadi lebih positif.

\section{Bersenang - senang}

Carilah hobi positif yang bisa membuat kamu bahagia, yang membuat kamu melupakan segala kepenatan. Jangan malu untuk tertawa lepas,

9. Istirahat yang cukup

Untuk mewujudkan kesehatan mental yang optimal, dibutuhkan istirahat yang cukup setelah melakukan aktifitas di siang hari.

\section{Kesimpulan :}

Selain kesehatan fisik, kesehatan mental menjadi salah satu hal terpenting. Dan edukasi kesehatan mental harus benar-benar diwujudkan, agar masyarakat tidak lagi memberikan stigma negatif kepada pengidap dan mampu memberikan perlakuan yang baik untuk mereka. Selain masyarakat juga lebih aware dengan kesehatan mental nya sendiri. Masyarakat mampu lebih peduli dengan sekitar. Tidak mudah memberikan judgement, tidak merendahkan dan meremehkan 
pengidap gangguan mental. Menciptakan lingkungan yang nyaman dengan belajar memanusiakan manusia.

\section{Daftar Pustaka :}

Kejarmimpi.id, "Indonesia Masih Darurat Stigma Tentang Kesehatan Mental." https://www.kejarmimpi.id/indonesia-masih-darurat-stigma-tentang-kesehatanmental.html , diakses pada 08 Oktober 2021

Cmph, 2020. “ Literasi Kesehatan Mental di Masyarakat, Apa Urgensinya?" https://cpmh.psikologi.ugm.ac.id/2020/09/29/literasi-kesehatan-mental-dimasyarakat-apa-urgensinya/, diakses pada 08 Oktober 2021

dr. Sahat Hamonangan H, M.Biomed,Sp.Kj, “Langkah Mudah Menjaga Kesehatan Mental.” $\quad$ https://rsudmangusada.badungkab.go.id/promosi/read/107/langkahmudah-menjaga-kesehatan-mental, diakses pada 08 Oktober 2021

D Ayuningtyas, 2018. "Analisis Situasi Kesehatan Mental Pada Masyarakat di Indonesia dan Strategi Penanggulangannya", http://ejournal.fkm.unsri.ac.id/index.php/jikm/article/download/241/189/363 , diakses pada 09 Oktober 2021

Karina, Z., \& Sodik, M. A. (2018). Pengaruh Dukungan Sosial Terhadap Kesehatan. 